\title{
Correction to: Proximity ligation scaffolding and comparison of two Trichoderma reesei strains genomes
}

\author{
Etienne Jourdier ${ }^{1 \dagger}$, Lyam Baudry ${ }^{2,3 \dagger}$, Dante Poggi-Parodi ${ }^{1}$, Yoan Vicq ${ }^{1}$, Romain Koszul ${ }^{2,3}$, Antoine Margeot ${ }^{1}$, \\ Martial Marbouty ${ }^{2,3^{*}}$ and Frédérique Bidard ${ }^{1 *} \neq$
}

\section{Correction to: Biotechnol Biofuels (2017) 10:151 https://doi.org/10.1186/s13068-017-0837-6}

Following publication of the original article [1], the authors reported a problem in the drawing of Rut-C30 chromosome III in Fig. $2 \mathrm{~b}$ of the original article [1]. The two fragments of chromosome I inserted inside chromosome III should be swapped, and the direction of the fragment containing rim101 and cella genes should be inverted. This reversed insertion indicates that at least 2 rearrangements occurred simultaneously, so the possible scenario proposed in Fig. 2c of the original article was inaccurate. The corrected Fig. 2 with modified panels b and $\mathrm{c}$ is available in this erratum. The detailed description of Rut-C30 assembly in the Additional file 5 of the original article is correct.

The authors also noticed two mistakes in chromosome numbering in the description of these translocations. The correct description is

"The three translocations resulted finally in the right arm of chromosome I ( $3^{\prime}$ end of scaffold 48 and main fragment of scaffold 5: $1.63 \mathrm{Mb}$ and 442 genes in total), to be swapped with the right arm of chromosome VI ( $3^{\prime}$ end of scaffold 22: $402 \mathrm{~kb}$ and 114 genes). But also in two fragments of chromosome I (one with a fragment of scaffold 4, and the other one

*Correspondence: martial.marbouty@pasteur.fr; frederique.

bidard-michelot@ifpen.fr

†Etienne Jourdier and Lyam Baudry contributed equally to this work

${ }^{\ddagger}$ Martial Marbouty and Frédérique Bidard contributed equally to this work

${ }^{1}$ IFP Energies nouvelles, 1 et 4 Avenue de Bois-Preau,

92852 Rueil-Malmaison, France

${ }^{2}$ Groupe Régulation Spatiale des Génomes, Department Genomes

and Genetics, Institut Pasteur, 75015 Paris, France

Full list of author information is available at the end of the article 


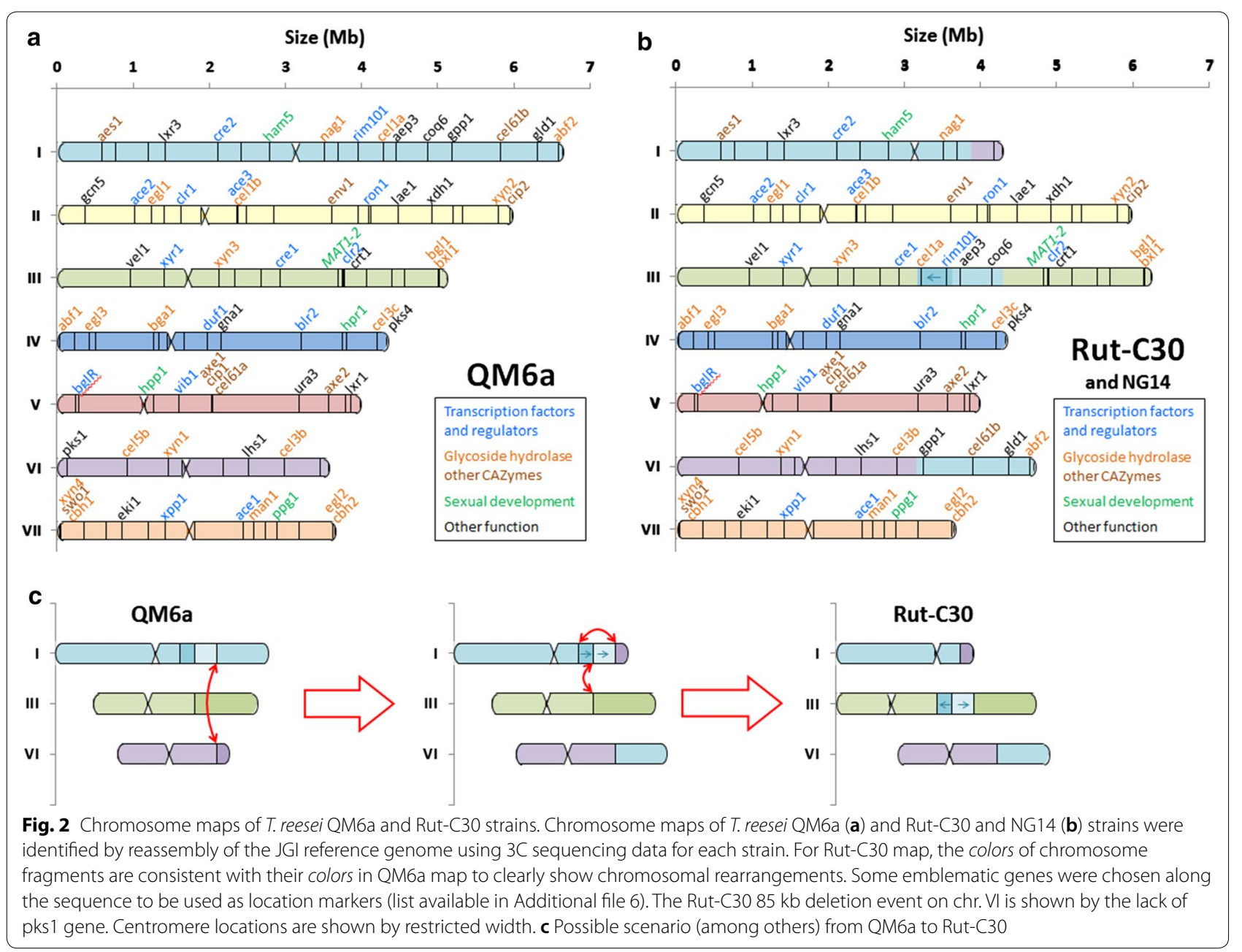

with another fragment of scaffold 4, scaffold 49 and a small fragment of scaffold 48) to be inserted head to foot in the middle of the chromosome III (1.13 Mb and 310 genes in total for both fragments)."

\section{Author details}

${ }^{1}$ IFP Energies nouvelles, 1 et 4 Avenue de Bois-Preau, 92852 Rueil-Malmaison, France. ${ }^{2}$ Groupe Régulation Spatiale des Génomes, Department Genomes and Genetics, Institut Pasteur, 75015 Paris, France. ${ }^{3}$ UMR 3525, CNRS, 75015 Paris, France.

The original article can be found online at https://doi.org/10.1186/ s13068-017-0837-6.

\section{Publisher's Note}

Springer Nature remains neutral with regard to jurisdictional claims in published maps and institutional affiliations.

Received: 29 May 2018 Accepted: 1 June 2018

Published online: 13 June 2018

\section{Reference}

1. Jourdier E, Baudry L, Poggi-Parodi D, Vicq Y, Koszul R, Margeot A, Marbouty M, Bidard F. Proximity ligation scaffolding and comparison of two Trichoderma reesei strains genomes. Biotechnol Biofuels. 2017;10:151. https://doi.org/10.1186/s13068-017-0837-6. 